\title{
ACCESS TO LEGAL REPRESENTATION BY CRIMINAL DEFENDANTS IN VICTORIA, 1861-1961
}

\author{
ALANA PIPER* AND MARK FINNANE**
}

\section{INTRODUCTION}

Traditionally under the English legal system, prisoners charged with felonies had been denied the right to legal representation on the grounds that such assistance was superfluous, perhaps even harmful to the cause of justice. ${ }^{1}$ Jurist William Hawkins, writing in the early $18^{\text {th }}$ century, declared that 'it requires no manner of Skill to make a plain and honest Defence', adding that the 'artless and ingenuous Behaviour of one whose Conscience acquits him' had 'something in it more moving and convincing than the highest Eloquence of Persons speaking in a Cause not their own'. ${ }^{2}$ However, it was also from the early $18^{\text {th }}$ century that defence counsel were gradually allowed to take part in the trials of those charged with serious crimes. Much has been written on how this fundamentally changed the nature of the criminal trial process in jurisdictions derived from the common law system, as we discuss later.

There has been far less consideration though, of how long it took for the presence of defence counsel to become standardised across the majority of criminal trials in the upper courts. Previous approaches to the history of legal representation generally focused more on the debates surrounding the introduction of the Prisoners' Counsel Act 1836, 6 \& 7 Wm 4, c 114 ('Prisoners' Counsel Act') and later development of incipient legal aid schemes, than on the implementation and effects of such legislation in terms of actual numbers of represented defendants. Indeed, to the best of our knowledge, there has been no historical quantitative research on the extent of legal representation in English,

* Dr Alana Piper, Research Fellow, Griffith University, holds a Postdoctoral Fellowship on the ARC Laureate Fellowship Project, 'The Prosecution Project'.

** Professor Mark Finnane, ARC Laureate Fellow and Professor of History, Griffith University, is director of the ARC Laureate Fellowship Project, 'The Prosecution Project'.

Acknowledgements: Research for this article has been supported by the Australian Research Council Laureate Fellowship Program (FL130100050, 2013-18) and the Griffith University Research Infrastructure Program (2014).

1 John H Langbein, The Origins of Adversary Criminal Trial (Oxford University Press, 2005) 33-6; David J A Cairns, Advocacy and the Making of the Adversarial Criminal Trial 1800-1865 (Oxford University Press, 1999) 4.

2 William Hawkins, A Treatise of the Pleas of the Crown: Or, a System of the Principal Matters relating to That Subject, Digested under Their Proper Heads (E and R Nutt and R Gosling, 1739) vol 2, 400. 
Australian or other like jurisdictions affected by the 1836 reform. In this article we explore the question using new data from Victoria across the years 18611961, providing the first longitudinal quantitative study of the rise of legal representation during the century preceding the establishment of modern legal aid schemes. In addition to considering the changing rates of use of defence lawyers in the criminal trial, we analyse the overall importance to the accused of the increasing availability of representation, and the impact of poor prisoner defence schemes, precursors of legal aid, in improving access to equal justice. On the basis of this Victorian evidence, we show that while defence counsel may have begun to appear in felony trials from the $18^{\text {th }}$ century and become more common from the $19^{\text {th }}$ century, levels of representation continued to be very uneven among those charged with serious crimes well into the $20^{\text {th }}$ century.

This article begins by tracing the origins of defence counsel's inclusion in felony trials by surveying the major scholarship in the history of legal representation and highlighting the current article's contribution. A brief outline of our methodology is followed by a discussion of the rate of representation in Victoria over time, in the context of changing legal, social and economic factors. Using the study's sample of trials of indictable crimes, we consider who had access to legal representation and how the background of defendants influenced their capacity to retain counsel. Finally, we conclude by considering the history of public provision of defence counsel to impoverished accused, and why the schemes introduced during the early $20^{\text {th }}$ century failed to deliver substantially increased levels of representation. A common thread considered throughout is the value to criminal defendants of having legal counsel, a topic of continuing relevance given the current trend towards cuts in legal aid funding.

\section{ORIGINS OF DEFENCE COUNSEL FOR CRIMINAL ACCUSED}

Under medieval common law, criminal defendants were prohibited access to legal assistance in the courtroom for felony matters, although it was allowed for those charged with misdemeanours. ${ }^{3}$ As we shall see, in many ways this was merely the start of what continued to be an uneven system in which - despite reforms - it was often the most vulnerable or at-risk defendants who lacked representation. The evolution of the adversarial trial in which justice became a contest between competing lawyers is typically traced to the late $17^{\text {th }}$ century, when a desire to avoid repetition of the treason trials of the $1680 \mathrm{~s}$ led to legislation allowing treason defendants to engage defence counsel. ${ }^{4}$ As David Cairns notes though, the shift to an adversarial mode would not be complete until at least the mid- $19^{\text {th }}$ century. ${ }^{5}$

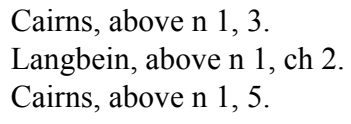


J M Beattie traces the earliest employment of defence counsel by prisoners accused of felonies to the $1730 \mathrm{~s} .{ }^{6}$ Their role was initially limited to helping their clients on points of law; they were still prohibited from speaking to matters of fact. ${ }^{7}$ As John Langbein explains, this was justified by the dubious claim that it was to a defendant's advantage that he speak for himself when it came to crossexamining witnesses and particularly to stating his own case - after all, the defendant would be much better informed than his lawyer as to the pertinent facts of what had occurred. ${ }^{8}$ Moreover, it was expected that the judge would also act as an unofficial advocate for the defendant in matters of both fact and law, including by questioning witnesses. ${ }^{9}$ However, across the $18^{\text {th }}$ century many judges began permitting defence counsel a more active role in felony trials, allowing them to conduct cross-examinations. ${ }^{10}$

From slow beginnings, Beattie reports that by 1788 a minimum of one in eight defendants tried for property offences at the Old Bailey had legal representation, and that by 1800 this had risen to between a quarter and a third of property crime defendants. ${ }^{11}$ According to Beattie:

The precise numbers are not important. What is plain is that counsel were commonly engaged in the defense of accused felons by the late eighteenth century and that they made a great difference to the way trials were conducted. ${ }^{12}$

Yet from another point of view the numbers are important. While the representation rate may have risen comparatively quickly to encompass a substantial minority of defendants by the early $19^{\text {th }}$ century, this does not mean that the presence of defence counsel became a standard feature in courtrooms across the $19^{\text {th }}$ or even much of the $20^{\text {th }}$ centuries. The numbers become all the more important given the proposition that the presence of defence counsel had a significant effect on trial outcome - as suggested by Beattie in a study comparing verdicts for clients of the $18^{\text {th }}$ century criminal lawyer William Garrow against the generality of criminal defendants. ${ }^{13}$

In 1836, legislation was enacted that guaranteed the right of all criminal defendants to employ legal counsel, and expanded the role of said counsel to include the right to state the defendant's case to the jury in summation. Many of the English bench and Bar were hostile to the Prisoners' Counsel Act, believing it would unnecessarily lengthen trials, or worse, obscure the evidence presented to juries. It was argued that the reform would aggravate inequality and injustice since prosecutors were "usually wealthier than the defendant and would be able to hire the better counsel'.${ }^{14}$ Godfrey and Lawrence have argued that this hostility did not simply disappear following the passage of the Act: 'many lawyers in fact

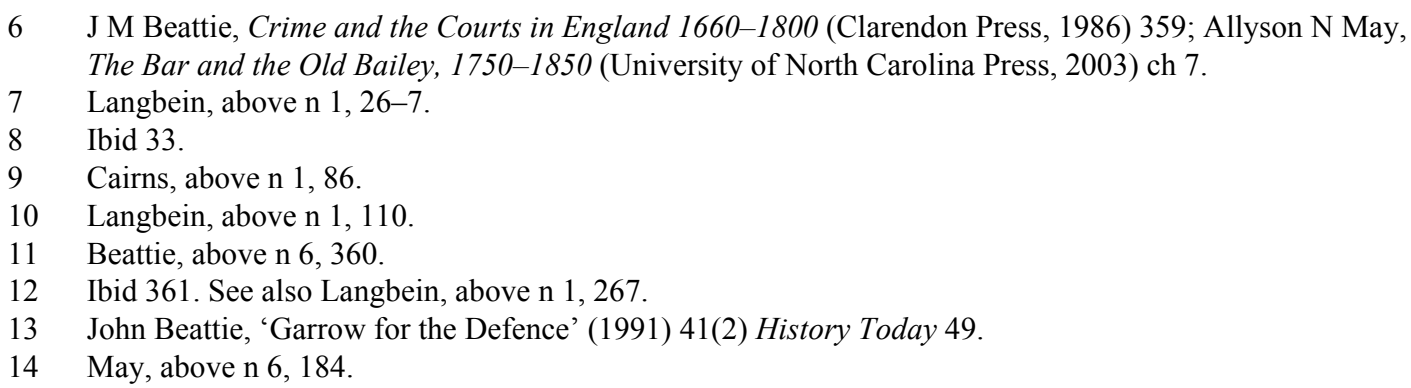


doubted its efficacy in the criminal courts and the public remained sceptical until quite late in the century'. ${ }^{15}$ Yet the Act was transformative. In a recent reassessment, Cerian Charlotte Griffiths points out that while the change was met with mixed feelings by barristers themselves, the Act was significant for making defence counsel 'a permanent fixture of the felony trial'. ${ }^{16}$

Unlike other Acts passed in England at the time, the Prisoners' Counsel Act was not adopted immediately in New South Wales (though it was in Tasmania, in 1837). ${ }^{17}$ As a result, the question of whether felons in New South Wales were entitled to employ defence counsel was the subject of an appeal case, Ex parte Nichols, in 1839. ${ }^{18}$ The Supreme Court affirmed the law as proclaimed in the Prisoners' Counsel Act, although a dissenting judge held that the statute was simply declaratory of the common law anyway. Chief Justice Dowling, displaying none of the reluctance of some of the English judiciary, went so far as to declare the right to counsel as a 'fundamental personal right' ${ }^{19}$ The matter was further resolved the following year when the colony passed the Defence on Trials for Felony Act 1840 (NSW), an Act later inherited by the colony of Victoria upon separation from New South Wales. In his history of colonial criminal law, Gregory Woods describes the passage of the Prisoners' Counsel Act and its subsequent adoption by the Australian colonies as 'one of the most important changes to English criminal law' to occur in the $19^{\text {th }}$ century. ${ }^{20}$ The legislation did not, however, erase all doubts about the desirability of defence lawyers' involvement in the criminal justice process, and it certainly did not guarantee their presence.

While the value of defence lawyers to the cause of justice in criminal trials remained in question by some, the advantages of their presence to the interests of defendants themselves was increasingly recognised. The early $19^{\text {th }}$ century saw the emergence of the adage that 'every man who is his own lawyer, has a fool for a client' ${ }^{21}$ From the 1820 s there were proposals in England to guarantee defence counsel to all those accused of capital crimes; by the late $19^{\text {th }}$ century it had become common practice in both England and Australia for judges to exercise their discretion by assigning counsel to impoverished accused facing a potential death penalty. ${ }^{22}$ Continued scepticism about the value of defence lawyers to the cause of justice meant that enlarging the public provision of legal assistance remained limited until the turn of the century. As Simon Smith observes in his

15 Barry Godfrey and Paul Lawrence, Crime and Justice since 1750 (Routledge, 2015) 57.

16 Cerian Charlotte Griffiths, 'The Prisoners' Counsel Act 1836: Doctrine, Advocacy and the Criminal Trial' (2014) 4 Law, Crime and History 28, 29.

17 An Act for Extending to this Colony Sundry Statutes Passed for the Amendment of the Criminal Law 1837 (Tas).

18 Ex parte Nichols (1839) 1 Legge 123, cited in G D Woods, A History of Criminal Law in New South Wales: The Colonial Period, 1788-1900 (Federation Press, 2002) 142-8.

19 Ex parte Nichols (1839) 1 Legge 123, 128 (Dowling CJ).

20 Woods, above n 18, 142.

21 Henry Kett, The Flowers of Wit, or a Choice Collection of Bon Mots, Both Antient and Modern with Biographical and Critical Remarks (Lackington, Allen and Co, 1814) vol 2, 185.

22 Cairns, above n 1, 47; John Adrian Lynch, Legal Aid and Legal Profession in Victoria 1841-1995: A Study in the Evolution of Professional Ideals (PhD thesis, La Trobe University, 1996) 79-80. 
analysis of the legal profession in $19^{\text {th }}$ century Victoria, the attitude of the profession itself during this period was generally that lawyers should not take on any cause that 'does not appear to be just' or where the facts were at least 'uncertain' or the law 'doubtful'. ${ }^{23}$

As several Australian legal scholars have documented, in the early to mid$20^{\text {th }}$ century attempts were made to enlarge access to legal representation through the introduction of poor prisoners defence schemes. ${ }^{24}$ As we discuss later in this article, before the establishment of modern legal aid systems in the 1960s and 1970 s, eligibility to access such schemes continued to be narrowly defined and administered in a haphazard manner. ${ }^{25}$ While the need for reforms points to the imperfect working of earlier schemes, previous histories have been able to offer only limited hard data as to representation rates before the late $20^{\text {th }}$ century period, when support (political and financial) for legal aid increased. The attitudes and issues charted in this article, however, are far from obsolete. Since the 1990s, legal aid in various Australian jurisdictions (as well as in the United Kingdom and United States) has suffered from funding cuts that have affected access to legal counsel, even for those accused of serious crimes. ${ }^{26}$ This makes a reconsideration of the pre-history of legal aid, and how the criminal justice system functioned in the period before representation became widespread, even more desirable.

\section{METHODOLOGY}

Systematic data relating to legal representation is being collected by the Prosecution Project, which has been digitising historical information on Supreme Court trials across multiple Australian jurisdictions. ${ }^{27}$ Our data therefore pertains to serious indictable offences; it might be presumed that representation rates were even lower among those charged with summary offences, but analysis of this possibility must await a future study. The primary data is collected from historic court registers or related record sets, by a process of manual transcription into a relational database. The case data reported in this article for Victoria draws on

23 Simon Smith, 'The Shaping of the Legal Profession' in Simon Smith (ed), Judging for the People: A Social History of the Supreme Court in Victoria 1841-2016 (Allen \& Unwin, 2016) 71, 75, quoting John W Willis (Handwritten Note, nd Box 55a, doc 26, 000195, Royal Historial Society of Victoria).

24 Mary Anne Noone and Stephen A Tomsen, Lawyers in Conflict: Australian Lawyers and Legal Aid (Federation Press, 2006) 24-34; Chris Field and Jeff Giddings, 'A History of Legal Aid in Victoria' in Jeff Giddings (ed), Legal Aid in Victoria: At the Crossroads Again (Fitzroy Legal Service, 1998) 20; Lynch, above $\mathrm{n} 22,72$.

25 Noone and Tomsen, above n 24, 46-8.

26 Jeff Giddings, John Dewar and Stephen Parker, 'Being Expected to Do More with Less: Criminal Law Legal Aid in Queensland' (1999) 23 Criminal Law Journal 69; Steven Rares, 'Is Access to Justice a Right or a Service?' (2015) 89 Australian Law Journal 777; Ed Cape, 'The Rise (and Fall?) of a Criminal Defence Profession' [2004] Criminal Law Review 401.

27 Mark Finnane et al, The Prosecution Project Database (version 1, 17 July 2016) $<$ https://prosecutionproject.griffith.edu.au/prosecutions $>$. For a discussion of the project's aims and methods, see Mark Finnane and Alana Piper, 'The Prosecution Project: Understanding the Changing Criminal Trial through Digital Tools' (2016) 34 Law and History Review 873. 
the Prosecution Project's transcriptions of the Registers of Criminal Trial Briefs, which include information such as name of accused, trial place and date, committal location and date, names of witnesses, judge, verdict, and sentence. ${ }^{28}$ The Registers date from as early as 1861 in Victoria and are continuous in their original format for more than 100 years. Our focus on Victoria is enabled by the unique quality of the Victorian court registers, which are more comprehensive than other Australian registers in their data coverage over the long duration we consider in this article. Over time (especially in the $20^{\text {th }}$ century) additional information was added to the basic case record, including matters such as appeal applications, the name of the prosecutor, whether the accused was defended and the name of their lawyer. This article makes use of a five-yearly sample of individuals scheduled to be tried in Victoria during the months of February, July and October between 1861 and 1961.

Not counting cases where the trials were postponed to another month and two cases where the outcome was unknown, there are 5572 indicted individuals in this sample, where prosecution terminated either in a trial verdict (3341), jury disagreement (88), guilty plea (1833) or in the prosecution abandoning the case (310). Of these 5572 individuals, 2685 are recorded as being defended, either in the trial registers, which noted such details fairly consistently from 1915 onwards and sporadically before this, or in newspaper coverage of trials located through the National Library of Australia's Trove database. ${ }^{29} \mathrm{~A}$ further 1741 individuals were confirmed as being undefended through the same sources. This leaves 1146 individuals whose defence status remains unknown.

A significant number of those whose defence status could not be verified either pleaded guilty or had the prosecution against them abandoned. In the latter instance, defendants may or may not have retained counsel in the expectation of going to court, but the discontinuation of proceedings against them simply means that a public record of this fact was seldom retained. Similarly, without the spectacle of a trial, the cases of those who pleaded guilty were less likely to receive substantial newspaper coverage, from which it might be possible to gather whether a defendant was represented. It seems likely though that many were not; whereas 32.9 per cent of the total sample (including those whose defence status was unknown) pleaded guilty overall, undefended accused pleaded guilty in 46.2 per cent of cases, while defended accused did so at a rate of only 23.5 per cent. Defendants who planned to plead guilty were presumably less inclined to retain a lawyer because they saw it as an unnecessary expense; the State took the same view when considering applications for legal assistance. ${ }^{30}$

For the purposes of this article, therefore, rates of representation are based on trials that proceeded to verdict. Eliminating defendants where the prosecution abandoned the case, a guilty plea was entered or the jury disagreed, still leaves a sizeable final sample of 3341 defendants. Even if only these cases are examined,

28 Office of the Crown Solicitor (Victoria), 'Criminal Trial Brief Register I' (Archived Records, VPRS 3523, Public Record Office Victoria, 1852-91); Office of the Crown Solicitor (Victoria), 'Criminal Trial Brief Register II' (Archived Records, VPRS 3524, Public Records Office Victoria, 1892-1961).

29 National Library of Australia, Trove (31 August 2016) $<$ http://trove.nla.gov.au $>$.

30 C M S Power, 'Legal Aid to Poor Persons' (1928) 2(12) Law Institute Journal 172, 173. 
however, the recording of an 'unknown' defence status does not appear random. It seems likely that a higher proportion of individuals given this designation were undefended than defended. During the $19^{\text {th }}$ century, newspapers usually reported the presence and name of defence counsel, but did not always specifically note that an accused was undefended. ${ }^{31}$ Nevertheless, as there are still likely to be defended accused among those whose status is unknown, our estimate of the numbers of those defended can only be described as a minimum rate of representation. In order to present the most conservative figures possible, we treat the figures of those listed as defended as a minimum representation rate, the approach also taken by Beattie in his study. ${ }^{32}$ This representation rate will be compared with those known to be undefended, and a total that also includes those of unknown representation status.

While the quantitative material forms the basis of the key conclusions of this article, we also draw on significant qualitative evidence from a variety of sources to consider the different factors that influenced the likelihood of defendants being able to access defence counsel. Major sources include newspaper reports, trial briefs from the sampled cases, appeal cases that turned on access to defence counsel and cases from the Public Record Office Victoria's series of criminal application files (1884-1962), which contains special requests relating to criminal trials, including applications for counsel. ${ }^{33}$ Evidence has also been drawn from memoirs and newspaper reports to illustrate contemporary attitudes to the desirability of criminal defendants charged with serious or indictable offences being able to access legal representation.

\section{AVAILABILITY OF LAWYERS OVER TIME}

How common was the use of defence counsel in the criminal trial in Victoria and did the likelihood of representation change over time? What role was played in access to legal defence by changes in the profession or by government intervention? The Prosecution Project data analysed below offers some important quantitative perspectives on these questions, which are then addressed in greater detail from a qualitative perspective in the later sections of this article.

Of the 3341 defendants in the final sample (covering the century from 18611961), at least 1953 of indicted accused were defended - a representation rate of 58.5 per cent of defendants across the century as a whole (see Table 1). As Table 1 shows, this rate varied across the century with a general upward trend, particularly during the $20^{\text {th }}$ century. As we discuss later, one of the most important factors likely to have shaped a significant increase in the $20^{\text {th }}$ century was the statutory provision for legal defence, dating in Victoria from 1916 (the representation rates for the periods before and after 1916 were 51.7 per cent and

31 See, eg, 'Supreme Court Criminal Sittings', The Argus (Melbourne), 21 October 1887, 11; 'Ballarat Court of Assize', The Ballarat Star (Ballarat), 21 October 1882, 4.

32 Beattie, above n 6, 360.

33 Supreme Court of Victoria, Criminal Application Files (Archived Records, VPRS 469, Public Record Office Victoria, 1884-1962). 
68.2 per cent respectively). The proportion of accused known to be undefended (908, or 27.2 per cent of the total sample) likewise fell across the period, from almost half of defendants in 1861 to just a third a hundred years later. As we will discuss later, representation rates varied not just over time but by defendant characteristics, with factors such as occupation, age, sex, ethnicity, conviction history and offence type influencing the likelihood of representation.

The data also underlines the significance of these differing representation rates by demonstrating the strong association of legal counsel with more favourable outcomes for defendants. Of the 1820 defendants in the sample found guilty on one or more charges, 47.4 per cent were defended compared to 71.7 of those who were outright acquitted. Meanwhile, undefended accused represented 35.9 per cent of the guilty defendants, compared to 16.8 per cent of those acquitted (see Table 2). This strong association between defence status and verdict largely holds irrespective of controls for other factors such as type of offence, location of trial, or defendant's sex, race or age. ${ }^{34}$ Furthermore, among defendants who were found or pleaded guilty, there was also an association between representation and sentence type, with representation improving a defendant's prospects of a non-custodial sentence (see Table 2). Consequently, since having legal representation was a strong predictor of trial outcome, the issue of who had access to representation is one of fundamental importance when considering the evolution of the criminal trial in Australia. So how did the availability of lawyers to criminal defendants change across time?

The supply of lawyers in some colonial settings was initially limited. In the early years, colonies relied on qualified lawyers immigrating to their shores; the first colonial barrister was not admitted to practise in Victoria until 1859, and a faculty of law was not established at the University of Melbourne until 1873. ${ }^{35}$ When Victoria separated from New South Wales in 1851, there were only six or seven barristers in practice to serve a population of about $80000 .{ }^{36}$ Understaffing in the legal profession may have had an especially severe impact on representation rates in criminal trials, due to the lower regard for criminal work traditionally held by lawyers, which meant that many of those working in criminal law were less experienced members of the profession still struggling to build a more lucrative civil practice. ${ }^{37}$

34 Alana Piper and Mark Finnane, 'Defending the Accused: The Impact of Legal Representation on Criminal Trial Outcomes in Victoria, Australia 1861-1961' (2017) 38 Journal of Legal History 27.

35 Arthur Dean, A Multitude of Counsellors: A History of the Bar of Victoria (Cheshire, 1968) 26. See also Smith, above $\mathrm{n} 23,77-8$ for more on educational requirements for barristers and solicitors in Victoria's early years.

36 Dean, above n 35, 25.

37 Philip A Jacobs, A Lawyer Tells (F W Cheshire, 1949) 64. 
Table 1. Representation rate across sampled years with chi square analysis*

\begin{tabular}{llll} 
Trial year & Total no. defendants & Defended \% & Change \% \\
\hline 1861 & 357 & 43.1 & $/$ \\
1866 & 228 & 49.6 & 6 \\
1871 & 150 & 54.7 & 5 \\
1876 & 167 & 56.3 & 2 \\
1881 & 162 & 57.4 & 2 \\
1886 & 140 & 49.3 & -8 \\
1891 & 166 & 41.6 & -8 \\
1896 & 158 & 46.8 & 5 \\
1901 & 131 & 54.2 & 8 \\
1906 & 135 & 60.7 & 6 \\
1911 & 89 & 55.1 & -5 \\
1916 & 93 & 77.4 & 22 \\
1921 & 117 & 69.2 & -8 \\
1926 & 115 & 70.4 & 9 \\
1931 & 224 & 65.6 & -5 \\
1936 & 108 & 67.6 & 2 \\
1941 & 112 & 73.2 & 6 \\
1946 & 173 & 78 & 5 \\
1951 & 158 & 65 & -13 \\
1956 & 177 & 64.4 & -1 \\
1961 & 182 & 63.7 & 58.5 \\
Overall sample & 3341 & 5 & 5 \\
\hline
\end{tabular}

${ }^{*} 0$ cells have expected count less than 5 across all analyses. $\chi^{2}(40)=518.94, p=.000$ 
Table 2. Impact of legal representation across different variables with chi square analysis*

\begin{tabular}{|c|c|c|c|c|c|}
\hline Variable & $\begin{array}{l}\text { Category of } \\
\text { defendant }\end{array}$ & $\begin{array}{l}\text { Total no. } \\
\text { defendants }\end{array}$ & $\begin{array}{l}\text { Defended } \\
\%\end{array}$ & $\begin{array}{l}\text { Undefended } \\
\%\end{array}$ & $\begin{array}{l}\text { Unknown } \\
\%\end{array}$ \\
\hline \multirow{2}{*}{ Verdicta } & Not guilty & 1,521 & 71.7 & 16.8 & 11.6 \\
\hline & Guilty & 1,820 & 47.4 & 35.9 & 16.7 \\
\hline \multirow{2}{*}{$\begin{array}{l}\text { Sentence } \\
\text { type }^{b^{* *}}\end{array}$} & Custodial & 2,718 & 35.3 & 42.6 & 22.1 \\
\hline & Non-custodial & 886 & 57 & 32.4 & 10.6 \\
\hline \multirow{3}{*}{ Time periodc } & Pre-1916 legislation & 1,976 & 51.7 & 28.3 & 20 \\
\hline & Post-1916 legislation & 1,365 & 68.2 & 25.6 & 6.2 \\
\hline & Property & 2,179 & 51.1 & 32.8 & 16.2 \\
\hline \multirow[t]{2}{*}{ Offence type ${ }^{d}$} & Personal & 849 & 72.9 & 16.1 & 11 \\
\hline & Other & 312 & 70.8 & 18.3 & 10.9 \\
\hline \multirow{2}{*}{ Trial locatione } & Regional & 1,071 & 57.5 & 28.9 & 13.4 \\
\hline & Metropolitan & 2,270 & 58.8 & 26.4 & 14.8 \\
\hline \multirow{2}{*}{ Defendant sex $x^{f}$} & Male & 3,040 & 58.1 & 27.6 & 14.3 \\
\hline & Female & 297 & 61.6 & 23.2 & 15.2 \\
\hline \multirow{2}{*}{$\begin{array}{l}\text { Defendant } \\
\text { ethnicityg }\end{array}$} & European & 3,224 & 58.6 & 27 & 14.4 \\
\hline & Asian & 94 & 55.3 & 30.9 & 13.8 \\
\hline \multirow{2}{*}{$\begin{array}{l}\text { Defendant } \\
\text { occupation }^{\text {h }}\end{array}$} & Working class & 835 & 46.2 & 36.3 & 17.5 \\
\hline & Middle class & 220 & 65.5 & 20.5 & 14.1 \\
\hline \multirow{2}{*}{ Defendant age $\mathrm{i}^{\mathrm{i}}$} & $<30$ years & 595 & 53.1 & 31.4 & 15.5 \\
\hline & $>=30$ years & 573 & 43.5 & 38.9 & 17.6 \\
\hline \multirow{2}{*}{$\begin{array}{l}\text { Prior conviction } \\
\text { historyj }\end{array}$} & No priors & 524 & 56.7 & 29.2 & 14.1 \\
\hline & Prior convictions & 428 & 34.3 & 41.6 & 24.1 \\
\hline \multirow{2}{*}{ Bail statusk } & On bail & 1,267 & 80.2 & 10.5 & 9.3 \\
\hline & On remand & 1,699 & 40.9 & 38.5 & 20.6 \\
\hline
\end{tabular}

${ }^{*} 0$ cells have expected count less than 5 across all analyses. ${ }^{*}$ Numbers on sentencing based on all convicted defendants, whether convicted by jury or having pleaded guilty.
a. $\chi 2(2)=209.89, p=.000$
b. $\chi^{2}(2)=140.24, p=.000$
c. $\chi 2(2)=146.17, p=.000$
d. $\chi 2(4)=145.38, p=.000$
e. $\chi 2(2)=2.71, p=.258$
f. $\chi 2(2)=2.57, p=.277$
g. $\chi 2(2)=.705, p=.703$
h. $\chi 2(2)=27.24, p=.000$
i. $\chi 2(2)=11.12, p=.004$
j. $\chi 2(2)=48.12, p=.000$
k. $\chi 2(2)=467.13, p=.000$ 
The supply of lawyers over time or in specific centres (in addition to their skill) may have influenced the fees they were able to charge. There is evidence that barristers who worked in the country during the $19^{\text {th }}$ century did better financially than those in Melbourne, possibly due both to a greater monopoly on cases and a higher fee structure. ${ }^{38}$ Yet we find little difference in the overall representation rates of metropolitan and regional defendants, which was 58.8 and 57.7 per cent respectively (Table 2 ).

When individual trial places are examined, however, a more interesting situation emerges. Three regional centres actually had higher representation rates than that found in Melbourne, namely Castlemaine and Bendigo (known officially as Sandhurst until 1891), both goldfields locations, and Sale, a prosperous farming centre that nevertheless benefitted greatly from the discovery of gold at nearby Omeo in 1851. Among the many migrants attracted to the colony during the 1850s' gold rush were a number of English and Irish barristers who made money not by digging for gold themselves, but profiting from the business created by the sudden influx of people and wealth. The profits to be made by lawyers in Victoria during the gold rush, when both the economy and crime figures were booming, were said to be substantial. In his memoirs William Manwaring, a Victorian police detective in the 1850 s and $1860 \mathrm{~s}$, recalled that at this time there had been at least a dozen lawyers at the Castlemaine goldfields who maintained 'enormous incomes' through criminal work, as 'almost every prisoner engaged counsel' ${ }^{39}$ Likewise, William Kelly recalled meeting an old acquaintance from England who had established himself as a solicitor in St Kilda, the suburb directly outside Melbourne on the road to the mining fields. Kelly's friend spoke 'slightingly of civil business', but assured him that an 'ordinary criminal case' meant 'a good year's income' ${ }^{40}$ The same source considered that barristers fared far less well during this period, eking out no more than a 'fly-blown existence' in small, soiled rooms as they competed with each other for referrals from affluent solicitors. ${ }^{41}$ By the 1860 s then, in Melbourne and the gold centres at least, it seems unlikely that access to representation was compromised by a shortage in the supply of lawyers. The minimum representation rate in 1861, while not as high as it would climb in subsequent

38 Rob McQueen, 'Together We Fall, Divided We Stand: The Victorian Legal Profession in Crisis 18901940' in W Wesley Pue and David Sugarman (eds), Lawyers and Vampires: Cultural Histories of Legal Professions (Hart Publishing, 2003) 293, 300-1.

39 William Henry Manwaring, 'Notes from His Diaries' (Manuscript, MS 13674, Box 15/9, State Library Victoria, 1897) 74.

40 William Kelly, Life in Victoria, or Victoria in 1853, and Victoria in 1858 Showing the March of Improvement Made by the Colony within Those Periods, in Town and Country, Cities and Diggings (Chapman and Hall, 1859) vol 1, 73. Kelly explained 'a good year's income':

... for a cut-throat-looking client in ragged apparel, by a simple surgical operation on his waistband, would half fill his hat with gold-dust, or extract from behind a patch on his coat a flake of fifty-pound notes that would paper a room - the one got on the gold-fields, the other on the highways. If there was an acquittal which, for the sake of society, was not generally desiderated - the enfranchised culprit rarely waited to enforce the striking of a balance; and if justice overtook him, there was rarely an heir, administrator, or assignee to demand a taxation of costs. Thus all the plunder remained with the solicitor. (emphasis in original). 
years, was still a fairly respectable 43.1 per cent. Five years later it had almost reached parity at 49.6 per cent.

Victoria and its legal profession continued to prosper until the 1890s, although the criminal business at the Supreme Court was nowhere near the levels of the first gold rush period. ${ }^{42}$ In 1890, Victoria entered a severe four-year economic depression. While this led to a rise in the incidence of some crimes, and thus more potential business for criminal lawyers, it also meant the capacity of many defendants to pay was diminished. The rate of representation, which had already dipped from 57.4 to 49.3 per cent between 1881 and 1886, dropped to 41.6 per cent in 1891, its lowest level across the entire sample period. The depression apparently compromised the ability of defendants to pay legal fees as they faced straitened circumstances or unemployment. These years also saw a rise in the proportion of property offences being tried, and property offenders were less likely to have legal representation than other categories of defendants (see Table 2).

The introduction of the Legal Profession Practice Act 1891 (Vic) might be expected to have affected the availability of counsel, although the evidence is ambiguous. Effectively this Act amalgamated the legal profession in Victoria, removing the former prohibition upon barristers acting in the capacity of solicitors or vice versa. ${ }^{43}$ The dissolution of the barrier between legal professionals was said by some to make it harder than ever for a barrister to build a successful practice. In 1896, Table Talk warned parents against sending their sons to practice at the already crowded Bar. ${ }^{44}$ During Victoria's 1899 Royal Commission into the administration of justice, several witnesses contended that the increased professional competition caused by amalgamation had decreased legal fees, but others conversely stated that costs to clients had increased as lawyers were forced to charge more in order to keep their practices viable. ${ }^{45}$ The effect of any increase or decrease in fees on access to legal representation appears to have been minimal; five years after the 1891 slump, the proportion of defended accused had shown a modest increase to at least 46.8 per cent of defendants.

In the sample considered here, the most significant shift in rates of representation occurred in 1916, when the representation rate reached a high point of 77.4 per cent. The shift may be explained a number of ways. First, the rate of defendants whose defence status is listed as unknown in this period declines, as the registers become more reliable in noting this information.

42 John Waugh, 'The Judges and Their Court, 1852-1900' in Simon Smith (ed) Judging for the People : A Social History of the Supreme Court in Victoria 1841-2016 (Allen \& Unwin, 2016) 98-101.

43 Smith, above n 23, 80-1; McQueen, above n 38.

44 'Anecdotal Photograph', Table Talk (Melbourne), 7 February 1896, 5. Three years later author Harry Furniss informed his English readers that the experiment of mixing solicitors' and barristers' practices had 'with one accord [been] condemned as injurious to both professions': Harry Furniss, Australian Sketches Made on Tour (Ward Lock and Co, 1899) 28.

45 Parliament of Victoria, Royal Commission for Inquiring as to the Means of Avoiding Unnecessary Delay and Expense, and of Making Improvements in the Administration of Justice and in the Working of the Law, Law Reform Report (1899) 122, 234, 378 ('Royal Commission Report into the Administration of Justice'). 
However, if the rise was due solely to unknown defendants now being identified as defended, this would not account for lower representation rates in subsequent years where the proportion of defendants with an unknown defence status continued to be low. Notably 1916 was a war-time year; with large numbers of men being called to overseas service, there appears a smaller overall number of defendants than in many other years. A lower number of trials may have increased competition in the legal profession and so positioned defendants to secure services more cheaply. Such a factor may account for a similar trend in 1941, which also saw a decline in the number of trials accompanied by a high representation rate of 73.2 per cent. It should be noted though that other years with a low number of trials did not necessarily result in higher representation rates. For example, 1936 saw less than half the number of trials compared to 1931, but the representation rate climbed just two per cent, although this may also be due to the lingering effects of the Great Depression.

Perhaps then, 1916 was significant because it denoted a period in which attitudes towards the desirability of defendants having counsel were starting to shift. Towards the end of the year, Victoria introduced its first Poor Prisoners Defence Act 1916 (Vic) to provide legal assistance to those of limited means. While this statute came into force in mid-October, meaning it was unlikely to have had much direct effect on the representation rate among the sampled defendants for that year, the general discussion and debate around the Bill may have had other influences. In particular, the Bill was proposed and passed because of increasing recognition that it was in the interests of justice for defendants to have a properly mounted defence at trial; consciousness of such rhetoric may have encouraged some in the legal profession to extend their pro bono work or offer reduced fees in a greater number of cases. On the other hand, the Bill may also have heightened awareness of the utility of having a lawyer among defendants, encouraging them to retain counsel.

Overall the rate of representation among defendants subsequent to the introduction of the 1916 scheme was much higher than defendants tried before this, with 68.2 per cent of defendants being defended post-1916, compared to 51.7 per cent of defendants before this (see Table 2). An examination of individual years, however, does not reveal a simplistic story of progressive growth ushered in by increased public provision of legal counsel. The representation rate actually declined between 1916 and 1921; it also declined between 1926 and 1931, despite amending legislation in 1928 that extended eligibility for legal aid. The dramatic increases in the representation rate during the 1940s to over three quarters of defendants, and a fall to just under two thirds of accused in the 1950s, do not appear especially linked to any changes in legal aid policies. While the overall growth in the representation rate during the $20^{\text {th }}$ century is likely attributable to the introduction of incipient legal aid schemes, it is clear that other factors remained at play in influencing representation levels, and moreover that a substantial proportion of defendants accused of serious crimes remained undefended. 


\section{UNEVEN ACCESS TO REPRESENTATION}

Representation rates varied over time, but also by the characteristics of the accused themselves. In the absence of effective legal aid provisions prior to the $1960 \mathrm{~s}$, the fears that had been expressed early in the $19^{\text {th }}$ century that the introduction of defence counsel into the courtroom would result in an unequal system of justice based on the class position of defendants were thus to some extent justified. ${ }^{46}$ Some indication of the inequitable distribution of legal resources is obtained by considering the different representation rates among occupational groups in the Prosecution Project sample reported here. Details of occupation were ascertained from prison records and newspaper reports for 1055 defendants. Not surprisingly, having the financial means to afford a lawyer made a significant difference to the likelihood of engaging one. Those employed as labourers, skilled tradespersons or in other working-class occupations had a representation rate of 46.2 per cent compared with 65.5 per cent for merchants, white-collar workers or other middle-class individuals (see Table 2). The inequalities of access were strongest in the $19^{\text {th }}$ century, when 40.6 per cent of working-class defendants had representation compared to 66.7 per cent of middle-class accused. In the $20^{\text {th }}$ century this gap lessened (perhaps due to a combination of the introduction of poor prisoners defence schemes, as well as rising standards of living among the working classes), with working-class representation rising to 52.2 per cent, while middle-class representation fell slightly to 64.2 per cent.

Apart from their greater financial resources, well-to-do defendants might also have been in a better position to be represented because they were more likely to number barristers or solicitors among their personal acquaintances. When postmaster James Green was convicted of embezzlement in 1861, his lawyer Alexander Keefer proceeded to act as his character witness prior to sentencing, stating that he had known Green since he was a boy. ${ }^{47}$ For other defendants, their background and employment history may have meant they felt confident in their ability to conduct their own defence at trial. Former police officer Ladislas Kossak went undefended at his 1891 appearance regarding the rape of his fifteenyear-old daughter; after initially pleading not guilty at his committal hearing, Kossak altered his plea at trial, apparently in exchange for the Crown Prosecutor and Gaol Governor speaking favourably on his behalf concerning his police and military record. ${ }^{48}$ Hangman Michael Gately was another who defended himself at trial in 1876; Gately's defence that he had been annoyed by local youths for some time past due to his unpopularity as the local executioner was not accepted as justification for the assault of which he was accused and he was sentenced to three years' imprisonment. ${ }^{49}$

\footnotetext{
46 See especially May, above n 6, 184, 188.

47 'Beechworth Circuit Court: Criminal Jurisdiction', Ovens and Murray Advertiser (Beechworth), 31 October 1861, 2.

48 'Second Day', The Maffra Spectator (Maffra, North Gippsland), 26 October 1891, 3; 'Supreme Court at Sale', The Gippsland Times (Sale), 26 October 1891, 3.

49 'Central Criminal Court', The Argus (Melbourne), 17 October 1876, 6.
} 
Even if defendants had money, they might not always have been able to access it in order to pay for their defence. Any money found on a prisoner's person at the time of their arrest was held in trust by police. Defendants could apply for the release of this money to cover their legal costs, but had to prove that the money in question was not the proceeds of crime. In applications for the release of funds to engage defence counsel, those who had been found in possession of large sums offered various explanations. Charles Rivers Allpress, a former accountant charged with stealing $£ 7000$ from the Commercial Bank at Collingwood in 1890, alleged that the money he had been carrying when arrested had been won gambling. ${ }^{50}$ After the judge expressed his dissatisfaction with this explanation and refused to allow Allpress to use any of the money for representation, Allpress immediately changed his plea from not guilty to guilty. ${ }^{51}$ Four years later, George Vincent, charged with a forgery that had netted him the more modest sum of a few hundred pounds, claimed that the money taken from him by police had been from the sale of a hairdressing business he had formerly operated in Sydney. ${ }^{52}$ Vincent was defended at trial but convicted anyway.

Alternatively, a defendant might have money but find it difficult to access it or contact counsel while remanded in gaol. Some gaol authorities proved obstreperous in the matter of allowing prisoners to seek and confer with counsel. Melbourne Gaol Superintendent John Buckley Castieau recorded his dislike of lawyers pushing their way in to see prisoners in 1874:

In the office to-day I was very much bothered with Mr Fisher the Barrister, he is a very pushing man \& has departed from the practice of Counsel in town which is not to visit the Gaol without an attorney. Mr Fisher not only does so but seeks work at the Police Court \& apparently follows it up to the Gaol in a manner even more earnest than most of the solicitors. I have a horror of touting \& am most anxious to escape any embroglio with the profession. I therefore try my best to prevent either barrister or attorney from visiting prisoners unless they have been sent for. ${ }^{53}$

Defendants also sometimes described difficulties negotiating for legal help from inside the gaol precincts. In 1895 Charles James Gordon, charged with two counts of obtaining goods by false pretences, applied for a postponement to his case; 'owing to confinement in Melbourne Gaol' he had only succeeded in raising the funds and securing a lawyer the day before the trial. ${ }^{54}$ The following year robbery defendant James Wilson likewise referred to the difficulty prisoners in Melbourne Gaol faced in preparing their defence. ${ }^{55}$ The Victorian trial registers contain bail information, enabling a comparison of the relationship between remand and being defended. Of defendants held in gaol, only 40.9 per cent were listed as defended. In comparison, the rate of representation among defendants on bail nearly doubled, reaching 80.2 per cent (see Table 2 ). This may be partly due

50 'Regina v Charles Rivers Allpress' (1890) in Criminal Application Files, above n 33, unit 1.

51 'Allpress before the Criminal Court', The Weekly Times (Melbourne), 21 June 1890, 21.

52 'Regina v George Vincent' (1894) in Criminal Application Files, above n 33, unit 1.

53 'Wednesday 7 January 1874' in John Buckley Castieau, 'The Diaries of John Buckley Castieau' (Manuscript, MS 2218, National Library of Australia, 1855-84).

54 'Regina v Charles James Gordon' (15 March 1895) in Criminal Application Files, above n 33, unit 2.

55 'A Notorious Criminal Pleads Guilty to Burglary', The Age (Melbourne), 16 July 1896, 5. 
to defendants released on bail having better financial resources that also helped in securing representation.

Yet throughout the study period, there were options for those without the immediate wherewithal to fund their own defence. Like other colonial jurisdictions, Victoria inherited the English practice that enabled the courts to appoint a lawyer if a defendant's case or background had certain features. Under Victoria's Crown Assignments scheme, given formal definition by the late $19^{\text {th }}$ century, destitute persons charged with capital offences, and Aboriginal Australians charged with any indictable offence, could apply to the Sheriff for representation. ${ }^{56}$ The quality of such counsel though remained questionable. In a memoir of his experiences as a lawyer and judge in late- $19^{\text {th }}$ and early- $20^{\text {th }}$ century New South Wales, Wilfred Blacket thus recalled that 'the most junior junior in court was assigned for the defence if the prisoner in a capital case was without coin or counsel' ${ }^{57}$ Blacket described the 'wrongdoings of [Aboriginal Australians]' as being a particularly 'welcome source of revenue' for new barristers as the courts always paid for their defence, providing lawyers following the circuit court with 'coach fare anyhow'. 58

Lawyers could also assist defendants by subsidising their fees, appearing pro bono, or by allowing clients to pay them off over time. Lawyers may have been particularly willing to reach accommodations in potentially high profile cases that would bring them good publicity if they mounted a successful defence. Prominent members of the Victorian Bar, for example, represented without payment the defendants tried for treason in 1855 in relation to events at the Eureka Stockade. ${ }^{59}$ Alternatively, friends, family, or employers could be enlisted for help. It was sometimes alleged that prostitutes and members of larrikin pushes would band together to raise the money for their various legal expenses. ${ }^{60}$ On the other hand, if a defendant was popular in the local community or if their case had garnered sympathetic attention at the committal stage, a collection might be taken up to cover their legal costs. In 1891, for instance, members of the local district raised funds for the defence of a domestic servant charged with perjury at Bendigo after she unsuccessfully brought a charge of sexual assault against her employer. ${ }^{61}$

The different means by which legal representation could be secured meant that certain types of offenders were more likely to receive legal help than others. Property offenders were far less likely to receive representation than other types

56 John Gavan Duffy, 'Regulations Relative to Defence of Destitute Persons Charged with Capital Crimes and of Aboriginals Charged with Indictable Offences' in Victoria, Victoria Government Gazette, No 30, 26 February 1892, 991, 1007; Francis Regan, 'Early Twentieth Century Australian Legal Aid: The

Overlooked Government Schemes' (2004) 11 International Journal of the Legal Profession 283, 289.

57 Wilfred Blacket, May It Please Your Honour: Lawyers and Law Courts of the Olden Times in New South Wales (Cornstalk Publishing, 1927) 247.

58 Ibid 237

59 Field and Giddings, above n 24, 20.

60 Victoria, Report from the Select Committee upon a Bill for the Prevention of Contagious Diseases, Parl Paper No 14 (1878) vol 1, 12; Victoria, Penal Establishments \& Gaols: Report of the Inspector-General for the Year 1890, Parl Paper No 44 (1891) 5.

61 'The Wycheproof Case', The Bendigo Advertiser (Bendigo), 3 October 1891, 4. 
of defendants, with a representation rate of 51.1 per cent against 72.9 per cent for those charged with crimes against the person and 70.8 per cent among those charged with other crimes (see Table 2). In part this was because most of the capital crimes that entitled defendants to assignment of a lawyer by the Crown were personal offences, in particular murder, rape, and carnal knowledge (these offences constituting approximately six per cent of the sample but around 10 per cent of those defended). By 1861 property crimes were only subject to capital punishment where they were compounded by violence, such as burglary with wounding. Yet even those charged with violent crimes that did not carry the possibility of the death penalty had a far higher proportion of defended prisoners than those charged with burglary, robbery, or stealing offences. The gap between the respective representation rates for property and personal offenders narrowed only slightly in the $20^{\text {th }}$ century, despite State-sponsored access to legal assistance being opened up more generally to all indictable offences.

This difference may have to do with the background of offenders likely to commit particular types of crimes. Property offenders were more likely to be recidivists than those accused of violent crimes (these two categories comprising the majority of crimes at the Supreme Court level). ${ }^{62}$ Recidivists were potentially less concerned by the prospect of gaol, as well as less financially empowered to meet legal fees; property offenders with no prior convictions had a higher representation rate (see Table 2). Attorneys too may have been less likely to take on property crime cases for a reduced fee, since the generality of such cases was probably less likely to be deemed 'meritorious' or sympathetic, or involve the types of legal complexities or notoriety that might help a lawyer make a name for themselves. The few property crimes with high representation rates were those like embezzlement and fraud, that were likely to attract a higher proportion of middle-class offenders. ${ }^{63}$

While defendants on capital charges in principle had access to representation, the sample shows this access was not guaranteed. In non-homicide capital cases in particular it seems likely the matter was sometimes overlooked. Following the conviction of Alexander Nelson for carnal knowledge of a six-year-old girl in 1871, there were complaints in the press that Nelson had been undefended at trial despite being entitled to apply for representation by the nature of the charge. ${ }^{64}$ Nelson was convicted and duly sentenced to death, but after appeals for clemency on his behalf the Executive Council commuted this to 12 years hard

62 This is consistent with contemporary findings: Jason Payne, 'Recidivism in Australia: Findings and Future Research' (Research and Public Policy Series No 80, Australian Institute of Criminology, 2007) 93-5.

63 In the sample, of 40 defendants charged with embezzlement whose occupations were identified, 33 were from middle-class backgrounds, as were 10 out of 16 defendants charged with fraud whose occupations were identified. For general discussion of growth of fraud and middle-class crime during the nineteenth century, see Sarah Wilson, The Origins of Modern Financial Crime: Historical Foundations and Current Problems in Britain (Routledge, 2014); George Robb, White-Collar Crime in Modern England: Financial Fraud and Business Morality, 1845-1929 (Cambridge University Press, 1992); Rob Sindall, 'MiddleClass Crime in Nineteenth-Century England' (1983) 4 Criminal Justice History 23.

64 Hugh Craig, 'The Convict Nelson', The Bendigo Advertiser (Bendigo), 21 February 1871, 2. 
labour, the first two in irons. ${ }^{65}$ The failure to provide counsel to accused in nonhomicide capital cases cannot be explained as the result of a belief that commutation was inevitable for such offences: another man, Oscar Wallace, would be hanged for rape in Victoria just two years later, despite having legal representation. ${ }^{66}$

Beyond the relevance of offence type to the incidence of legal representation, the personal characteristics of prisoners may have also affected the receipt of State legal assistance, or of lawyers' own pro bono work, or support by local or other informal networks. Personal attributes with the strongest correlation with defence status were the related factors of age and conviction history. Younger defendants were more likely to be defended than older ones. Those aged under 30 years had a representation rate of 53.1 per cent, compared to 43.5 per cent among those aged above 30 years (see Table 2). This was presumably because younger defendants were perceived as being in greater need of protection both by officers of the court and by those with personal connections to the accused, such as families or employers, who may have felt compelled to contribute towards their defence. Younger defendants were also likely to have had more limited previous contact with the justice system, and so their cases may have seemed more meritorious to lawyers taking on pro bono work, or officials adjudicating legal aid applications. Similar perceptions presumably also influenced the higher representation rate of those without prior convictions (56.7 per cent), compared to those with prior convictions (34.3 per cent) (see Table 2). As previously suggested, repeated contact with the justice system likely also served to weaken a defendant's financial resources.

Racial background may have had an impact on defence status, although the correlation appears less strong than in regard to age or previous convictions. This may be partly due to the low numbers of non-Europeans in the sample, with 3224 defendants identified as European, with a representation rate of 58.6 per cent (see Table 2). The 94 Asian defendants were only slightly less likely to have legal counsel at 55.3 per cent - almost all of these were Chinese, many of them likely to have benefited from the communitarian assistance provided through Chinese fraternal associations. ${ }^{67}$ The samples of defendants from Aboriginal or other racial backgrounds were too small to yield meaningful results, but they do suggest divergent trends. Of 7 Aboriginal defendants, 5 were charged with murder and defended; the remaining two were charged with robbery, one of whom was defended and one with an unknown defence status. Meanwhile, of the 16 defendants of colour from other racial backgrounds, including the Middle East and African diaspora, only 5 were defended.

Did a defendant's sex impact on representation rates, as it did many other aspects of the justice process? Initial observation suggests not, with the divergence between male and female representation rates weak, rising only a few points from 58.1 per cent among males to 61.6 per cent among females.

65 'Melbourne', The Ballarat Courier (Ballarat), 1 March 1871, 2.

66 'Execution of Wallace', The Ballarat Courier (Ballarat), 12 August 1873, 2.

67 See Mark Finnane, 'Law as Politics: Chinese Litigants in Late Colonial Court-Rooms' (2013) 9 Journal of Chinese Overseas 193. 
However, while there was little difference in representation rates across the overall sample, this obscures important shifts over time. In the $19^{\text {th }}$ century the respective representation rates of men and women were 49 and 48.4 per cent, although in the earliest decades men were decidedly more likely to have representation, perhaps due to their economic advantage. By the 1890s the rates began to shift in favour of women, and in the $20^{\text {th }}$ century sample period men and women had respective representation rates of 65.6 and 76.1 per cent. Although the overall low number of women (297 in total sample) limits the statistical significance of this difference, it does suggest that women perhaps benefitted more from legal assistance schemes.

While the current study thus reveals much about the personal and contextual factors associated with the historic likelihood of having the benefit of defence counsel, it also points to the need for more detailed studies of the dynamics of obtaining representation. Offence type was significantly associated with legal representation, in part through institutional factors, such as the expectation that those facing capital charges should be defended. Economic advantage certainly also played its role, and so the rise of legal assistance schemes is reflected in significant $20^{\text {th }}$ century increases in the rate of representation, although having representation remained far from standard. In the next section we consider the development of this public provision of legal counsel, and why the schemes introduced in this era did not automatically lead to an overwhelming proportion of defendants enjoying access to representation.

\section{PUBLIC PROVISION OF LEGAL COUNSEL}

To understand the continuously significant levels of undefended accused revealed in our data, the unsatisfactory nature and administration of Statesponsored legal services must be examined. Public provision of legal counsel to criminal defendants began in the Australian colonies with the practice of assigning counsel to accused in capital cases under the system known as 'Crown Assignments'. ${ }^{68}$ Bushranger Ned Kelly was defended as a Crown assignee; as presumably occurred with other prisoners whose counsel was court-appointed, Kelly's case was dealt with by an extremely junior barrister. ${ }^{69}$ The maximum fee for a defence under a Crown Assignment was seven guineas per day at the time of Kelly's trial, whereas a prominent barrister could easily charge 50 guineas or more per day to appear..$^{70}$ In 1892 , new regulations lifted the fee to 10 guineas or a maximum of 14 guineas where two counsel were required. ${ }^{71}$ It is not clear how often Crown Assignments were utilised; but based on the money expended on the scheme, it has been estimated by John Lynch that in the decade prior to the

68 Lynch, above n 22, 79.

69 Ibid 81-2; Louis Waller, 'Regina v Edward Kelly' in Colin F Cave (ed), Ned Kelly: Man and Myth (Cassell Australia, 1968) 105, 113-14.

70 Field and Giddings, above n 24, 21.

71 Duffy, above n 56, 1007. 
introduction of the Poor Prisoners Defence Act 1916 (Vic), Crown Assignments were only made between six and 24 times a year. ${ }^{72}$

By the late 1890s, however, disquiet had started to be voiced in Victoria about the plight of the undefended. ${ }^{73}$ Several witnesses to the 1899 Royal Commission expressed concerns that recent increases to costs of counsel limited the number of those who were able to secure help. ${ }^{74}$ Considerable interest was shown in the issue of public defence for prisoners during the early 1900s, as legal aid provisions were debated throughout Australia and internationally. A formal system of legal aid was introduced in England with the Poor Prisoners' Defence Act 1903. This encouraged calls for similar measures in Australia. Newspaper articles were published comparing the representation afforded to accused persons in other countries, principally in England and Scotland, but also in Europe and America. ${ }^{75}$ Legal aid societies based on legal professionals volunteering their services had been established in the United States from the late $19^{\text {th }}$ century, most notably in Chicago in $1888,{ }^{76}$ with earlier American organisations dating back to the 1860 s also catering to the needs of special groups of defendants such as destitute women. ${ }^{77}$ While there had always been an expectation among the legal profession in Victoria that lawyers should accept cases of 'merit' even where defendants were not able to afford their usual fee, there were no formal obligations to do so, or organisations to which needy defendants might apply.

With the establishment of a federal jurisdiction shortly after Federation in 1901, the most comprehensive access to legal assistance in Australia was established under the Judiciary Act 1903 (Cth). Section 69 provided that any person, charged with any indictable offence under Commonwealth law, who was 'without adequate means' to retain defence counsel could apply to a Supreme Court (in its federal jurisdiction) for a lawyer to be appointed to them, provided they did so within 14 days of being committed for trial. While the phrase 'without adequate means' suggests that legal aid was to be granted to defendants who without assistance could not afford counsel, the liberality with which the judiciary judged such applications is questionable.

The first applicant for legal aid in a federal case was Olive Douglas, a Melbourne prostitute charged with electoral impersonation in 1904. The defendant had voted under the name of her friend, fellow prostitute Fanny Montgomery. Douglas had submitted a postal ballot paper under Montgomery's name after a justice of the peace had visited the brothel where she resided and convinced a number of women there to apply for postal votes. Douglas had not cast a vote in her own name, despite being on the electoral roll. When asked why she had submitted a vote under the name Montgomery, Douglas pointed out that

72 Lynch, above n 22, 81.

73 'Lawyers' Costs in Trivial and Undefended Cases', The Bendigo Independent (Bendigo), 17 August $1897,2$.

74 Royal Commission Report into the Administration of Justice, above n 45, 95, 124.

75 'State Defence of Prisoners', The Evening News (Sydney), 11 October 1904, 4.

76 Albert F Bigelow, 'Epitome of Legal Aid History in the United States 1876-1925' (1926) 124 Annals of the American Academy of Political and Social Science 20, 20.

77 Felice Batlan, 'The Birth of Legal Aid: Gender Ideologies, Women, and the Bar in New York City, 18631910’ (2010) 28 Law and History Review 931, 932. 
as her own name was not really Douglas, and Montgomery's name was not really Montgomery (it being the practice among prostitutes to use aliases), she did not think it mattered what name she voted under. She had not thought her housemate Montgomery was planning to vote; the fraud had been discovered when Montgomery tried to cast a ballot on election day. ${ }^{78}$

Shortly after Douglas was committed for trial, an application for legal aid was made for Douglas by her solicitor Edward Kane. Kane explained that he had been paid to act for Douglas at the committal hearing by the woman who ran the brothel where Douglas lived, but Douglas herself was a person 'without means'. ${ }^{79}$ After reading the affidavits, Hodges $J$ refused the application, pointing out that the evidence that she was 'without means' seemed to rest simply on the statement that she was a 'resident of Lonsdale Street', an avenue notoriously associated with poverty and prostitution. ${ }^{80} \mathrm{~A}$ few days later though the application was again put before Hodges J and granted, as further evidence of Douglas's impecunious position had been obtained. ${ }^{81}$ In June, Douglas was defended by barrister $\mathrm{Mr}$ Eagleson and acquitted. ${ }^{82}$

Apart from the evidence required to prove a defendant's poverty, confusion prevailed about the procedural aspects of nominating and approving a defence counsel, both under the Crown Assignment scheme and the subsequent poor prisoners defence legislation. Under the Crown Assignment scheme, a defendant would notify the Sheriff that they were destitute, and at the same time nominate a solicitor and barrister to act on their behalf if their application for aid was successful. Difficulties arose in the 1911 case of alleged abortionist Laura Fox, however, when the Attorney-General refused to approve her nomination of George Arnot Maxwell, a barrister with a formidable reputation. No justification was given for this refusal; Fox was simply asked to nominate another barrister. ${ }^{83}$

The move attracted considerable comment in legal circles, as it was felt that the Attorney-General had no basis or right to refuse a prisoner's nomination of a specific lawyer if their general application for legal counsel had been granted. ${ }^{84}$ Forced to comment as a result of press attention, the Attorney-General gave as his reason that in another recent case where Maxwell had been retained as counsel he had returned the brief at the last minute. Maxwell then published a scathing reply to the Attorney-General, pointing out that he had been unable to act in the case in question due to another trial on which he was engaged running long, and that such occurrences were by no means uncommon among those with active practices. Maxwell also hinted that the real reason for the snub was personal animosity from the Attorney-General. ${ }^{85}$ The following day the AttorneyGeneral reiterated his position, stating that he believed he was justified in vetoing

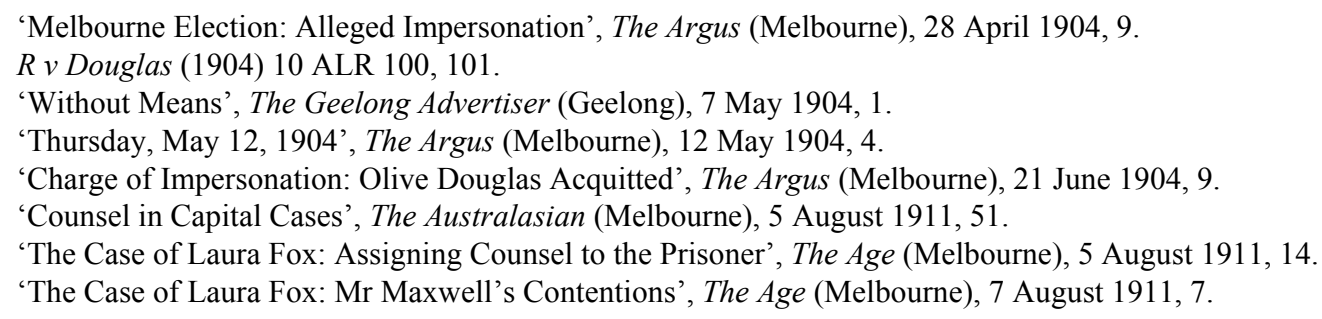


applications where there was reason to expect that court time might be lost through a last-minute change in counsel. ${ }^{86} \mathrm{~A}$ fortnight later, however, Maxwell was confirmed as counsel for Fox. ${ }^{87}$ Perhaps the problem all along was that the prosecution was aware of the case's weakness, as a few days later a nolle prosequi was entered against Fox. ${ }^{88}$

Legal assistance in Victoria remained very much a matter of discretion under both the pre and post-1916 schemes. Even if a defendant applied for legal assistance on seemingly reasonable grounds, this was by no means a guarantee that help would be forthcoming. In 1915 for instance, a solicitor made an application for funds for the defence of James Waters. Waters was charged with conspiracy in relation to larceny of a cheque, and the solicitor pointed out that the complexities of the charge were such that questions of law were likely to arise during the trial. The costs of counsel were beyond Waters; he was a labourer at the Mooroopna Cemetery earning four pounds a month, on which he had to support a wife and seven children. His only asset was a dray, which he had used as the security for the three pounds lent to him to cover the solicitor's costs during the committal hearing. ${ }^{89}$ Waters' application was nevertheless refused; unrepresented at trial, he was convicted and sentenced to twelve months' hard labour..$^{90}$

A ruling by the Victorian Court of Appeal in 1917 explicitly determined that poverty alone was not sufficient grounds to grant an application for legal aid under the state's Poor Prisoners Defence Act 1916 (Vic). In the case $R v$ Gould, ${ }^{91}$ it was accepted that the defendant, who was charged with attempting to shoot his wife, was in destitute circumstances and without friends. Woinarski submitted for the Crown that the presiding Judge had been right to refuse Gould's application for legal aid, as 'no special reason' had been given for such aid 'beyond that of poverty'. ${ }^{92}$ Chief Justice Madden in his ruling pointed out that the Act empowered judges or police magistrates to grant legal aid if they considered it 'in the interests of justice' to do so. ${ }^{93}$ In Madden CJ's opinion, this meant that there had to be 'some intricacy in the facts of the charge or some legal difficulty as likely to arise upon the trial' that justified making the public assume the costs of legal representation. ${ }^{94}$ In 1920, the Victorian Supreme Court in banco was relieved of any future responsibility for deciding disputed legal aid petitions by ruling that the Attorney-General was the ultimate authority in such cases. ${ }^{95}$

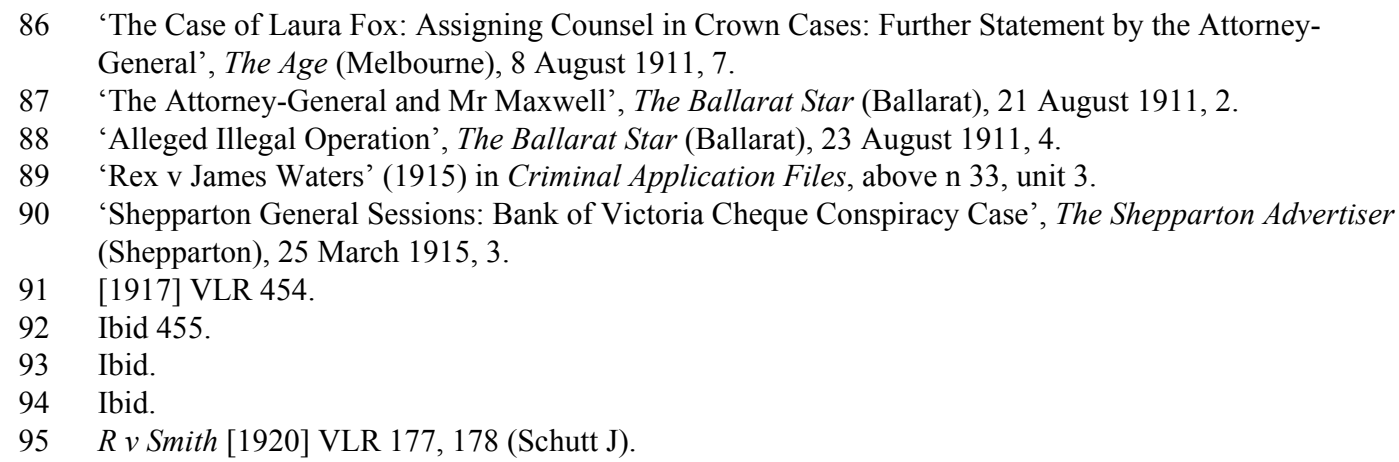


Some prisoners complained at trial that their applications had been refused without explanation. ${ }^{96}$ Other prisoners urged in their defence, or in mitigation of their sentence, that they had been unable to make such an application for assistance due to interference from the gaol authorities. ${ }^{97}$ Newspapers also sometimes queried why certain defendants had not been granted legal assistance, particularly if they appeared to be intellectually disabled. ${ }^{98}$ Defendants in the Victorian sample who had legal representation were more likely to have a longer wait between committal hearing and trial, with a mean wait time of 49.4 days compared to 38.13 days among defendants known to be undefended and 44.9 days in the overall sample. This may be partially due to postponements needed to allow defendants to secure counsel; it was also probably the result of requests for postponements from lawyers themselves to enable them to secure evidence for the defence.

By the inter-war period the opinion was regularly expressed that the dependence of access to legal representation on an individual's economic resources was a disadvantage that 'should not be tolerated in a democratic community'. ${ }^{99}$ The topic was canvassed in Australian legal journals, one noting in 1928 that assistance for poor persons had been enshrined in Scottish law since 1424. ${ }^{100}$ While judges thought legal assistance should only be granted in intricate cases, newspaper reports were pointing out that all criminal trials were 'governed by highly technical rules, which not one layman in a thousand thoroughly understands'. ${ }^{101}$ Legal literacy among the common populace may have also declined as newspaper coverage itself was changing. During the $19^{\text {th }}$ and early $20^{\text {th }}$ century, the minutiae of trials were reported in detail in the Victorian press, often by lawyers seeking additional income. ${ }^{102}$ As this practice declined, possibly as a result of trials becoming lengthier, public familiarity with the legal process may well have been affected, exacerbating the disadvantage of being undefended. This may be why the sample data shows representation had a bigger impact on the odds of acquittal in the $20^{\text {th }}$ than the $19^{\text {th }}$ century..$^{103}$

Fortunately for some, access to representation was being extended. Important amending legislation was also passed in Victoria in 1927 and 1928. ${ }^{104}$ The restrictive interpretation of the initial Act led to the 'in the interests of justice' clause being dropped in the subsequent 1927 legislation. ${ }^{105}$ In 1928, the Public Solicitor's Office was also created in Victoria. Lynch identifies 1928 as an important turning point in the history of legal aid in Victoria, moving it from

\footnotetext{
96 'Rights of Poor Prisoners: How Act Operates', The Argus (Melbourne), 7 February 1924, 7; 'Shooting with Intent: Incident at Willaura', The Argus (Melbourne), 13 November 1929, 10.

97 'Indecent Assault: 12 Months for Brady', The National Advocate (Bathurst), 4 February 1921, 4.

98 'Legal Assistance', The Don Dorrigo Gazette and Guy Fawkes Advocate (Dorrigo), 14 October 1922, 4.

99 “"British Justice": Where Law is Unfair', The Advocate (Devonport and Burnie), 27 December 1926, 1; see also 'Legal Aid for the Poor: Trials and Actions', The Sunday Mail (Brisbane), 29 November 1931, 2.

100 Power, above n 30, 172.

101 "'British Justice": Where Law is Unfair', above n 99, 1.

102 Jacobs, above n 37, 30.

103 Piper and Finnane, above n 34.

104 Poor Persons Legal Assistance Act 1927 (Vic); Poor Persons Legal Assistance Act 1928 (Vic).

105 Poor Persons Legal Assistance Act 1927 (Vic), s 4.
} 
some state subsidisation of legal aid in criminal trials that employed barristers on a volunteer basis, to the creation of a Public Solicitor's Office that meant legal aid could be administered in a less ad hoc manner. ${ }^{106}$

However, problems remained. A 1928 article in the Law Institute Journal on the operation of legal assistance in Victoria criticised the limited facility for a defendant who pleaded guilty in the lower court to receive representation at trial, even though they might have a good case for at least mitigation of penalty. ${ }^{107}$ This claim appears supported by the high number of undefended accused among those pleading guilty, noted earlier. The poor communication of the provisions of the Poor Persons Legal Assistance Act to accused persons (thereby preventing them from making applications for aid, or making them effectively) was also criticised. ${ }^{108}$ Throughout the 1930s and 1940s, there were continual complaints about lack of staffing and support in the Public Solicitor's Office. ${ }^{109}$ According to Field and Giddings, the refusal rate of requests for aid in criminal cases in the 1930s ranged from just over half to more than two thirds of cases. ${ }^{110}$ The interwar period saw little legislative development on the issue of legal service provision.

This changed in 1942, when the Legal Service Bureau was created to provide free legal advice and subsidised legal representation to members and former members of the armed services and their dependents. ${ }^{111}$ Perhaps relatedly, 1946 was another high point for Victoria's representation rate, which climbed to 76.9 per cent. The issue of legal assistance began to receive renewed attention in the post-war era. New Acts were passed in other states during the 1950s and 1960s. ${ }^{112}$ The issue of legal aid not only became a greater priority for governments, but the legal profession itself. In Victoria, this resulted in the Legal Aid Act 1961 (Vic), which stated in its preamble that 'the members of the Legal Profession of Victoria believe that no person should be without legal assistance by reason of his being unable to pay therefor'. An individual's qualification for legal aid was importantly to be determined not by magistrates or judges, but by a committee consisting of members from the Victorian Bar Council and the Council of the Law Institute of Victoria. Nevertheless the enormous post-war growth in criminal cases, partly associated with population growth, continued to put pressure on access to aid - rates of refusal of legal aid by the Public Solicitor's Office in the 1950 s and early 1960 s were as high as they had been in the 1930s. ${ }^{13}$ Statutory reform by way of the Legal Aid Act 1969 (Vic) enabled a major reduction in

\footnotetext{
106 Lynch, above n 22, 99.

107 Power, above n 30, 173.

108 Ibid.

109 Lynch, above n 22, 109.

110 Field and Giddings, above n 24, 23.

111 Ibid 23.

112 Legal Assistance Act 1954 (Tas); Legal Assistance (Amendment) Act 1957 (NSW); Legal Assistance Amendment Act 1964 (NSW); Poor Persons Legal Assistance Act Amendment Act 1968 (SA); Poor Persons Legal Assistance Act Amendment Act 1969 (SA).

113 Lynch, above n 22, 116.
} 
refusal rates, and eligibility thresholds for legal assistance were likewise relaxed in other states. ${ }^{114}$

\section{CONCLUSION}

In 1992, the High Court of Australia in Dietrich $v$ The Queen unanimously expressed the view that legal representation in criminal cases, particularly those involving serious crimes, was highly desirable if not necessary to ensure a fair trial. ${ }^{115}$ As Chief Justice Mason and Justice McHugh expressed it:

In our opinion. and in the opinion of the maiority of this Court. the common law of Australia does not recognize the right of an accused to be provided with counsel at public expense. However. the courts possess undoubted power to stav criminal proceedings which will result in an unfair trial. the right to a fair trial being a central pillar of our criminal iustice svstem. The power to grant a stav necessarilv extends to a case in which representation of the accused bv counsel is essential to a fair trial, as it is in most cases in which an accused is charged with a serious offence. ${ }^{116}$

In the end, a majority agreed that, while the right to a fair trial was not to be equated with a right to counsel at public expense, if an indigent accused had been unable to secure legal assistance it was unfair to proceed against them until they had representation. How indigence was to be measured, however, was not specified. Meanwhile, reductions in legal aid funding and government funding of the community legal sectors in recent years have placed increased pressure upon the private sector for the provision of free legal services to needy defendants. ${ }^{117}$

We have shown in this article that the introduction of defence counsel to criminal courts in the early $19^{\text {th }}$ century did not by any means ensure that clients of the court might access such representation. The availability of quantitative analysis of longitudinal data on the criminal trial in Victoria, enabled by the Prosecution Project, allows us to measure the rate of representation in ways previously impossible. Analysis of factors that have shaped access to legal defence is also now possible through such data. A defendant's likelihood of being placed in the more favourable position of having representation has never been random: apart from the impact of time and the introduction of legal assistance schemes, representation rates have historically been influenced by such factors as type of offence, bail status, occupation, age, and conviction history. While sample sizes reported here limit our conclusions, race and sex may also have exerted an effect, pointing to the need for future analysis in this area with expanded datasets. Analysis of the introduction of poor prisoners defence

114 Ibid 117; Noone and Tomsen, above n 24, ch 1.

115 Dietrich $v$ The Queen (1992) 177 CLR 292. See also George Zdenkowski, 'Defending the Indigent Accused in Serious Cases: A Legal Right to Counsel?' (1994) 18 Criminal Law Journal 135; Janet Hope, 'A Constitutional Right to a Fair Trial? Implications for the Reform of the Australian Criminal Justice System' (1996) 24 Federal Law Review 173.

116 Dietrich v The Queen (1992) 177 CLR 292, 298.

117 Rowena Maguire, Gail Shearer and Rachael Field, 'Reconsidering Pro Bono: A Comparative Analysis of Protocols in Australia, the United States, the United Kingdom and Singapore' (2014) 37 University of New South Wales Law Journal 1164. 
legislation in the early $20^{\text {th }}$ century shows that efforts to address such imbalances by ensuring more equal access to representation were hampered by lack of clarity as to the proper administration of legal assistance schemes. In light of this, the question of the importance, impact and equity of legal representation in criminal trials seems one that is worthy of further and continued attention by both historians and contemporary legal scholars. 